\title{
Evaluation of Material Characteristics of Xylite - Part 1. Influence of Moisture Content on Some Mechanical Properties
}

\section{Procjena obilježja ksilita - Dio 1. Utjecaj sadržaja vode na mehanička svojstva}

\author{
Original scientific paper • Izvorni znanstveni rad \\ Received-prispjelo: 8. 2. 2013. \\ Accepted-prihvaćeno: 6. 11. 2013. \\ UDK: $630 * 814.8 ; 630 * 812.462 ; 630 * .812 .7$ \\ doi:10.5552/drind.2013.1309
}

\begin{abstract}
The structure of xylite as lithotype of lignite indicates that it predominately originates from tree stems, from the family Taxodiaceae or Cupressaceae. Despite drastic changes in the long term process of its transformation, it retains some relevant properties of wood, nowadays applicable for specific products. The research examined the influence of moisture content and temperature on modulus of elasticity (MOE) and modulus of rupture (MOR) as well as shear strength and hardness. With decreasing of moisture content, the bending strength and stiffness of xylite increased and was best fitted by power regression model. The increasing of testing temperature from $20^{\circ} \mathrm{C}$ to $80^{\circ} \mathrm{C}$ had negative effect on stiffness and bending strength of xylite. The hardness was positively correlated with density of xylite, whereas shear strength had the opposite tendency.
\end{abstract}

Keywords: xylite, moisture content, modulus of elasticity, modulus of rupture, shear strength, hardness

SAŽETAK • Građa ksilita, litotipa lignita, pokazuje da on većinom potječe iz stabala porodica Taxodiaceae $i$ Cupressaceae. Usprkos drastičnim promjenama u dugotrajnim geološkim procesima transformacije, ksilit je zadržao neka važna svojstva drva. U istraživanju je ispitivan utjecaj sadržaja vode i temperature ksilita na njegov modul elastičnosti i modul loma pri savijanju, kao i na smicajnu čvrstoću te na tvrdoću. Sa smanjivanjem sadržaja vode u ksilitu posmična čvrstoća i modul elastičnosti poboljšavaju se. Ovisnost najbolje opisuje potencijski regresijski model. Podizanje temperature s 20 na $80^{\circ} \mathrm{C}$ negativno je utjecalo na modul elastičnosti i čvrstoću savijanja ksilita. Tvrdoća ksilita bila je u pozitivnoj korelaciji s gustoćom, a modul lomsmicajna čvrstoća se s povećanjem gustoće smanjila.

Ključne riječi: ksilit, sadržaj vode, modul elastičnosti, modul loma pri savijanju, smicajna čvrstoća, tvrdoća

\footnotetext{
${ }^{1}$ Authors are professor and assistant professor at University of Ljubljana, Biotechnical Faculty, Department of Wood Science and Technology, Ljubljana, Slovenia.

${ }^{1}$ Autori su profesor i docent Odjela za znanost o drvu i drvnu tehnologiju, Biotehnički fakultet Sveučilišta u Ljubljani, Ljubljana, Slovenija.
} 


\section{INTRODUCTION}

\section{UVOD}

Xyilite is a lithotype of lignite, also known as xyloid lignite or fossil wood, mined in various parts of Europe, United States, India and Australia. In Slovenia lignite is found in the Velenje basin, which is tectonically controlled intermountain basin filled by a succession of Pliocene and Plio-Quarternary sediments more than $1000 \mathrm{~m}$ thick (Markič and Sachenhofer, 2010). The lower part of swamp should be covered with grass like vegetation, surrounded by bushes and than by higher woody plants and trees. Vegetation (plants) covered with water should be subject to gradual but strong diagenetic and epigenetic changes reflected by a strong petrological heterogeneity as well as highly variable geotechnical properties and behavior in different underground coal layers (Brezigar, 1985/86). The Velenje seam formed during the transition from the fluvial to lacustrine one. Petrographical investigations confirmed a zonation of lignite, changing from xylite rich layer characteristic for the outer and lower part of the lignite seam, to fine detrital layer predominating in the inner and upper part of the seam. Galaficational basis without distinctive structure (derit) prevails with approximately $60 \%$, the content of wood tissue with recognizable cellular xylem structure (tekstit) amounts to $40 \%$ and there is a small amount of fizit (Drovenik, 1982; Justin and Markič, 2005). The form and structure of xylite indicate that it originates from tree stems. The investigation revealed that xylite mainly consists of traheids and contains uniseriate and homocellulare rays, taxodioid like cross-field pits, and abundant axial parenchyma with inclusion. Axial or radial resin channels were not observed (Gorišek et al., 2012). The observed features are typical of conifers of the family Taxodiaceae (e.g. genera Taxodium, Sequoia, Sequoiadendron) and Cupressaceae (e.g. genera Juniperus, Chameacyparis, Cupressus).

The structure of wood underwent considerable changes during the long term process of conversion from wood to xylite due to biochemical, geochemical and geological factors as well as carbonization (duration approx. 2 million years). The conversion of wood components is strongly influenced by environmental conditions. Submersion and underground embedding initiate very slow process of fossilization (Fengel, 1991) and solid state ${ }^{13} \mathrm{C}$ nuclear magnetic resonance and microscopic analysis showed good preservation of the cellulose structure so that fossil cellulose could not be degraded by cellulases and anaerobic microorganisms usually involved in the biodegradation of organic substances (Lechien at al., 2006). The most distinctive chemical changes are identified as gradual hydrolyzation or otherwise degradation of carbohydrates, while lignin structure remains more or less stable, and consequently its relative proportion increased (Hatcher et al., 1981; Hatcher et al., 1982; Drobnjak and Mastalerz, 2006). The polyoses are continuously degraded as acidic groups split off and cause an in-situ acid hydrolyses (Fengel, 1991). Changes of lignin molecules are held in interdependent reactions of oxidation, demetylation, loss of hydroxyl groups and condensation, which lead to more condensed structures (Fengel, 1991, Crook et al. 1965).

Chemical changes with interaction of mechanical stress resulted in deformity of individual cells, tissues or whole pieces of plants. High compressive forces acting in radial and tangential directions resulted in completely collapsed early wood cells. Latewood cells, which had thicker and more rigid cell walls, were less damaged. Due to collapse of cell walls into lumina, the density of xylite is high (the oven dry density of xylite was $1216 \mathrm{~kg} / \mathrm{m}^{3}$, whereas the basic density was only $873 \mathrm{~kg} / \mathrm{m}^{3}$, due to large volumetric shrinkage) but the capillary structure and hygroscopic characteristic of wood are preserved (Gorišek et al., 2012).

The appearance of xylite resembles that of precious wood species with dark heartwood and when it does not contain great amounts of mineral inclusions, it can be processed with wood working machines. Especially when polished, it often shows recognizable structure of wood and its color looks like wood species with dark colored heartwood, such as wenge (Milletialaurentii) or ebony (Dyospiros sp.).

Xylite remains hygroscopic; therefore it should be dried to the appropriate moisture content, which can ensure dimensional stability during use (Gorišek et al. 2012). Consequently, with varying moisture, adequate changes of mechanical properties can be expected.

The present study is focused on determination of some basic and processing-relevant mechanical properties of xylite, and on possible use of xylite as a substitute for valuable, tropical wood species. Due to its high sorption capacity, the influence of temperature and moisture content on examined mechanical properties of xylite is studied.

\section{MATERIAL AND METHODS} 2. MATERIJAL I METODE

The xylite for the experiment originates from the Velenje basin in Slovenia. Individual pieces were selected from the regular production line of lignite mine. Since xylite is petrographic strongly heterogeneous with a large variation of geotechnical properties, our sampling was based on visual assessment of material by selecting the xylite with the best preserved wood structures. We cut out all mineral inclusions and kept the most conserved material with recognizable structure of wood, which allowed us to make quite well xylotomic oriented slices without visible growth features of injury incurred during xylite formation.

The mechanical properties were tested at two temperature levels $\left(T_{1}=20^{\circ} \mathrm{C}\right.$ and $\left.T_{2}=80^{\circ} \mathrm{C}\right)$; first in green state, immediately after cutting the specimens from the xylite blocks, and then after equilibrating at four different relative humidities $(R H)$ achieved in thermostatically controlled chambers with the saturated salt solutions $\left(R H_{1}=34 \%\left(\mathrm{MgCl}_{2}\right), R H_{2}=65 \%\right.$ $\left(\mathrm{NaNO}_{2}\right), R_{3}=75 \%(\mathrm{NaCl})$ and $\left.R H_{4}=87 \%\left(\mathrm{ZnSO}_{4}\right)\right)$. 
To determine the modulus of elasticity $(M O E)$, standard 3-point static bending test was used (EN 310). As the cross section of all samples was not identical, it varied namely between 6 by $15 \mathrm{~mm}$ to 10 by $25 \mathrm{~mm}$ ( $h$ by $b$ ), it was attempted to avoid the shear contribution at selected samples with the constant span to thickness ratio of 17 . The bending modulus of elasticity was obtained as:

$$
M O E=\frac{l^{3}}{4 \cdot b \cdot h^{3}} \cdot \frac{\Delta F}{\Delta y}
$$

where $l$ is the distance between the supports, $b$ and $h$ are the width and thickness of the sample, $\Delta \mathrm{F}$ is the load increment and $\Delta \mathrm{y}$ is deflection increment corresponding to the load increase $\Delta \mathrm{F}$.

With determination of the ultimate load $\left(F_{\max }\right)$ at failure, the bending strength, i.e. modulus of rupture $(M O R)$ was evaluate as:

$$
M O R=\frac{3 \cdot F_{\max } \cdot l}{2 \cdot b \cdot h^{2}}
$$

Shear test parallel to the grain was carried out on a $20 \mathrm{~mm}$ cube using the Zwick-Roell Z100 universal testing machine. The cube was loaded at a rate of 2 $\mathrm{mm} / \mathrm{min}$. The tests were made on parallel specimens in the radial and tangential planes. The shear or rigidity modulus $(G)$ was estimated within the elastic range on stress-strain diagram, whereas the shear strength $(\tau)$ was calculated at ultimate load of rupture.

Hardness $(H B)$ of xylite was determinate by a standard test method according to EN 1534. The penetration depth $(h)$ of iron sphere $(D=10 \mathrm{~mm})$ was used in calculations at load $F=1000 \mathrm{~N}$ to determine the Brinell hardness of xylite by Eq. 3 .

$$
H B=\frac{2 \cdot F}{\pi \cdot D \cdot\left(D-\sqrt{D^{2}-4 \cdot h \cdot(D-h)}\right.}
$$

\section{RESUL TS AND DISCUSSION}

\section{REZULTATI I RASPRAVA}

The long-term influence of various bio-geochemical factors of xylite development results in considerable changes not only of structure but also of mechanical properties of xylite. Despite the long process, the investigated mechanical properties of xylite remained close to the values of original wood species (the family Taxodiceae or Cupressaceae), but it cannot be related to the woods with similar density (c.f. ebony or wenge). Comparable values of mechanical properties of fossil conifers resulted in well preserved cell wall structure especially with still well organized cellulose. Due to its crystalline order, cellulose resists hydrolysis for a long time and slowly degradation is observed in samples with ages up to 1 million years (Fengel, 1991). It seems that continuous degradation of polyoses has minor effect on the strength of xylite. Visible changes of aging and fossilization are recognized in specific fracture, which is instantaneous and more brittle.

The mechanical properties of xylite varied with moisture content, as well as with the testing temperature. The influence of temperature on mechanical properties of xylite is more pronounced in determination of stiffness, and less in determination of strength properties (Tab. 1). The most distinctive reduction of stiffness and bending strength of xylite with increased testing temperature, with the ratio around 2.1 (between $M O E$ at $20^{\circ} \mathrm{C}$ and $80^{\circ} \mathrm{C}$ ) and 1.4 (for $M O R$ at the same temperature interval), was perceived at about $14 \% M C$, which was the average equilibrium moisture content (EMC) of xylite at normal climate $\left(20^{\circ} \mathrm{C} / 65 \%\right)$.

Based on data from the literature (Dinwoodie, 2000), linear dependence of strength from temperature changes was assumed within the investigated temperature range.

Similarly as wood, the marked increase in strength upon drying from the fiber saturation point to lower $M C$ was determined for xylite, while the amount of free water filling the capillaries in elements did not

Table 1 Influence of moisture content $(M C)$ and temperature $(T)$ on modulus of elasticity $(M O E)$ and modulus of rupture of xylite (MOR).

Tablica 1. Utjecaj sadržaja vode u drvu $(M C)$ i temperature $(T)$ na modul elastičnosti $(M O E)$ i na modul loma pri savijanju ksilita $(M O R)$

\begin{tabular}{|c|c|c|c|c|c|}
\hline \multicolumn{3}{|c|}{$\begin{array}{c}\text { Temperature / Temperatura } \\
T=20^{\circ} \mathrm{C}\end{array}$} & \multicolumn{3}{c|}{$\begin{array}{c}\text { Temperature / Temperatura } \\
T=80^{\circ} \mathrm{C}\end{array}$} \\
\hline $\begin{array}{c}\text { Moisture content } \\
\text { Sadržaj vode } \\
\text { MC, \% }\end{array}$ & $\begin{array}{c}\text { Modulus of } \\
\text { elasticity } \\
\text { Modul elastičnosti } \\
\text { MOE, GPa }\end{array}$ & $\begin{array}{c}\text { Modulus of } \\
\text { rupture } \\
\text { Modul loma pri } \\
\text { savijanju } \\
\text { MOR, MPa }\end{array}$ & $\begin{array}{c}\text { Moisture content } \\
\text { Sadržaj vode } \\
\text { MC, \% }\end{array}$ & $\begin{array}{c}\text { Modulus of } \\
\text { elasticity } \\
\text { Modul elastičnosti } \\
\text { MOE, GPa }\end{array}$ & $\begin{array}{c}\text { Modulus of } \\
\text { rupture } \\
\text { Modul loma pri } \\
\text { savijanju } \\
\text { MOR, MPa }\end{array}$ \\
\hline 41.0 & 5070 & 35.5 & 40.5 & 4232 & 29.0 \\
\hline 26.2 & 6604 & 57.5 & 26.5 & 4646 & 43.9 \\
\hline 18.9 & 10148 & 76.6 & 19.1 & 5911 & 58.4 \\
\hline 13.9 & 11868 & 96.8 & 14.2 & 5743 & 69.5 \\
\hline 6.3 & 13758 & 148.7 & 6.0 & 13232 & 135.9 \\
\hline
\end{tabular}


affect stiffness and strength above FSP, which was 36.0 $\%$ (Gorišek et al., 2012). As known, the increase is even more significant for wood. The MOE of dried xylite at room temperature was 2.7 times greater than in the fresh state. The difference is greater at higher temperature $\left(80^{\circ} \mathrm{C}\right)$, where the ratio is 3.1 . An even more pronounced difference is observed when comparing the $M O R$ of raw and dried samples. The phenomena can be ascribed to very high hygroscopic potential of xylite (Gorišek et al., 2012), where a large amount of water may reduce the cohesion and strength of the material with high $M C$. In fresh condition the $M O R$ is 4to 5-times lower than in the driest state. All dependencies of $M O R$ and $M O E$ on $M C$ within the examined range can be successfully fitted into power regression model with high determination coefficient (Fig. 1 and Fig. 2).

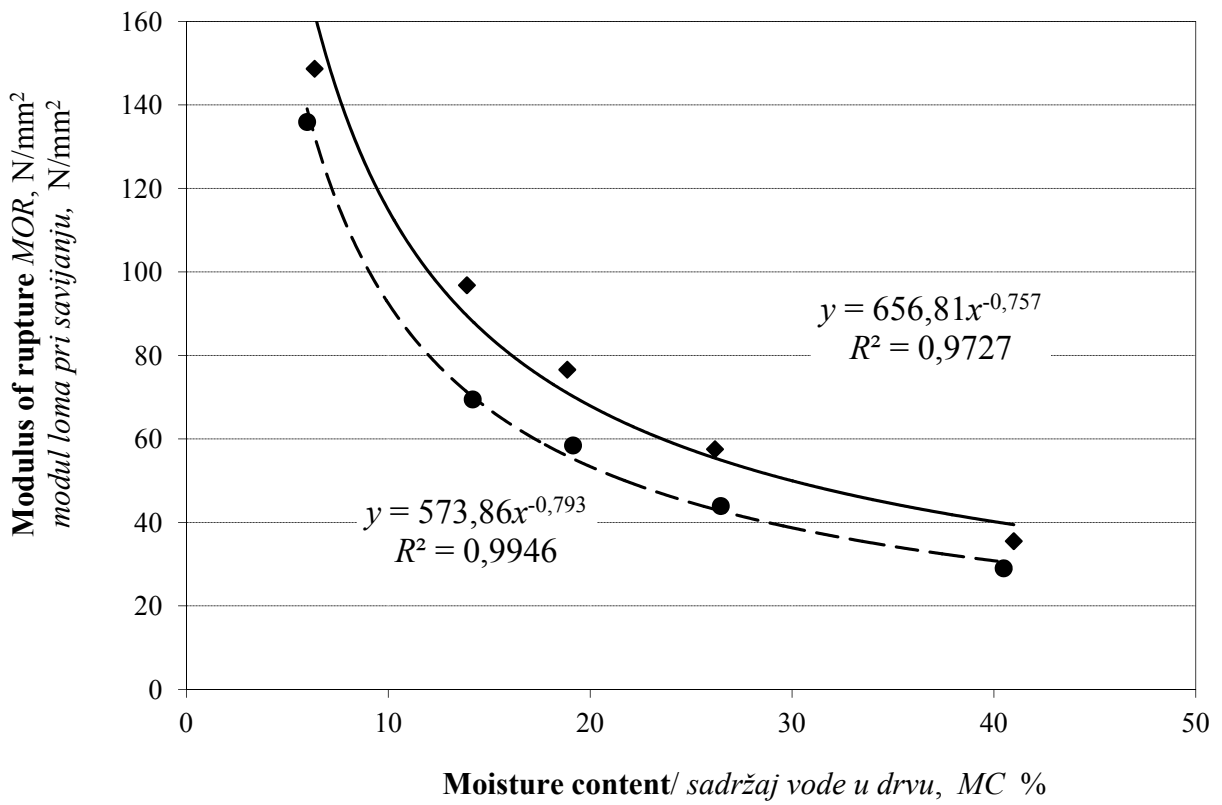

Figure 1 Influence of moisture content $(M C)$ on modulus of rupture $(M O R)$ at $20^{\circ} \mathrm{C}(\diamond)$ and $80^{\circ} \mathrm{C}(\bullet)$.

Slika 1. Utjecaj sadržaja vode u drvu na modul loma pri savijanju pri temperaturi $20^{\circ} \mathrm{C}(\bullet) \mathrm{i}$ $80{ }^{\circ} \mathrm{C}(\bullet)$

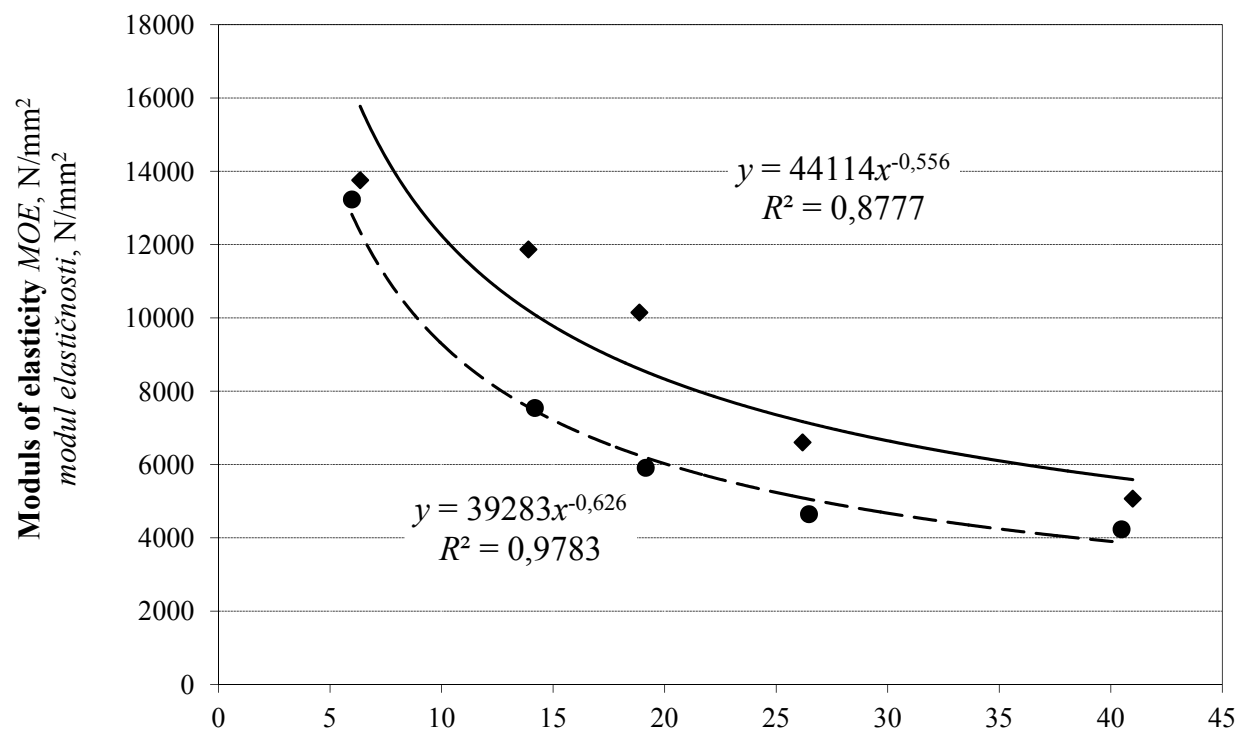

Moisture content / sadržaj vode u drvu, MC \%

Figure 2 Influence of moisture content $(M C)$ on modulus of elasticity $(M O E)$ at $20^{\circ} \mathrm{C}(\bullet)$ and $80^{\circ} \mathrm{C}(\bullet)$

Slika 2. Utjecaj sadržaja vode u drvu na modul elastičnosti pri savijanju uz temperaturu $20^{\circ} \mathrm{C}(\bullet)$ i $80{ }^{\circ} \mathrm{C}(\bullet)$ 
The high values of shear strength of xylite, compared to similarly dense and structurally alike current wood species were in some way unexpected (Tab. 2), so that great variability need to be considered (Dinwoodie, 2000). Relatively high average value of shear strength can be partly explained by interwoven tissue, while specimens with straight grain and tangential orientation reached tremendously low strength. Breaking of some samples immediately after loading had also to be taken into consideration and therefore a substantial number of samples had to be eliminated from further assessment. Much of fractures had been initiated during the drying process, which was confirmed by research on drying of this material (Gorišek and Straže, 2014). Some fractures were only observed at microscopic level, so that only $30.0 \%$ to $56.9 \%$ of dried xylite can be used for further manufacturing.

Table 2 Average values and basic statistics for shear modulus $(G)$, shear strength $(\tau)$ and hardness $(H B)$ of xylite

Tablica 2. Prosječna vrijednost i osnovna statistika modula smicanja $(G)$, čvrstoće na smicanje $(\tau)$ i tvrdoće $(H B)$ ksilita

\begin{tabular}{|l|c|c|c|}
\hline & $\begin{array}{c}\text { Shear modulus } \\
\text { Modul smicanja } \\
G, \mathrm{GPa}\end{array}$ & $\begin{array}{c}\text { Shear strength } \\
\text { Čvrstoća na smicanje } \\
\tau, \mathrm{MPa}\end{array}$ & $\begin{array}{c}\text { Hardness } \\
\text { Tvrdoća } \\
\text { HB, MPa }\end{array}$ \\
\hline Average & 4.4 & 30.1 & 91.7 \\
\hline No.of samples & 16 & 16 & 20 \\
\hline St.dev. & 1.31 & 10.05 & 18.7 \\
\hline C.V: & 29.6 & 33.4 & 20.4 \\
\hline Min. & 2.3 & 12.5 & 57.9 \\
\hline Max. & 6.2 & 40.7 & 118.3 \\
\hline
\end{tabular}

It was interesting to observe the relation between density of xylite and its shear strength. Density had a negative impact on shear strength (Fig. 3), while the influence of density on hardness was positive with high prediction strength of fitted linear regression model (Fig. 4).

The latter result was expected due to the confirmed presence of highly collapsed cells in xylite, with positive impact on its density (Gorišek and Straže, 2013). On the other hand, densification is presumably not the only consequence of collapsing, but also rupturing of the structure with the resulting reduction in strength, determined by shear tests. Higher density was also observed when xylite contained more soil or min- eral inclusions. Generally, they are arranged in series with relatively great influence on shear strength reduction.

\section{CONCLUSIONS \\ 4. ZAKLJUČAK}

Long time influence of geological and biochemical factors on wood during its conversion into xylite is reflected not only on its structure but also on its mechanical properties.

The quality of mechanical properties of xylite was just slightly lower than the quality of mechanical properties of wood from which it originated. The high

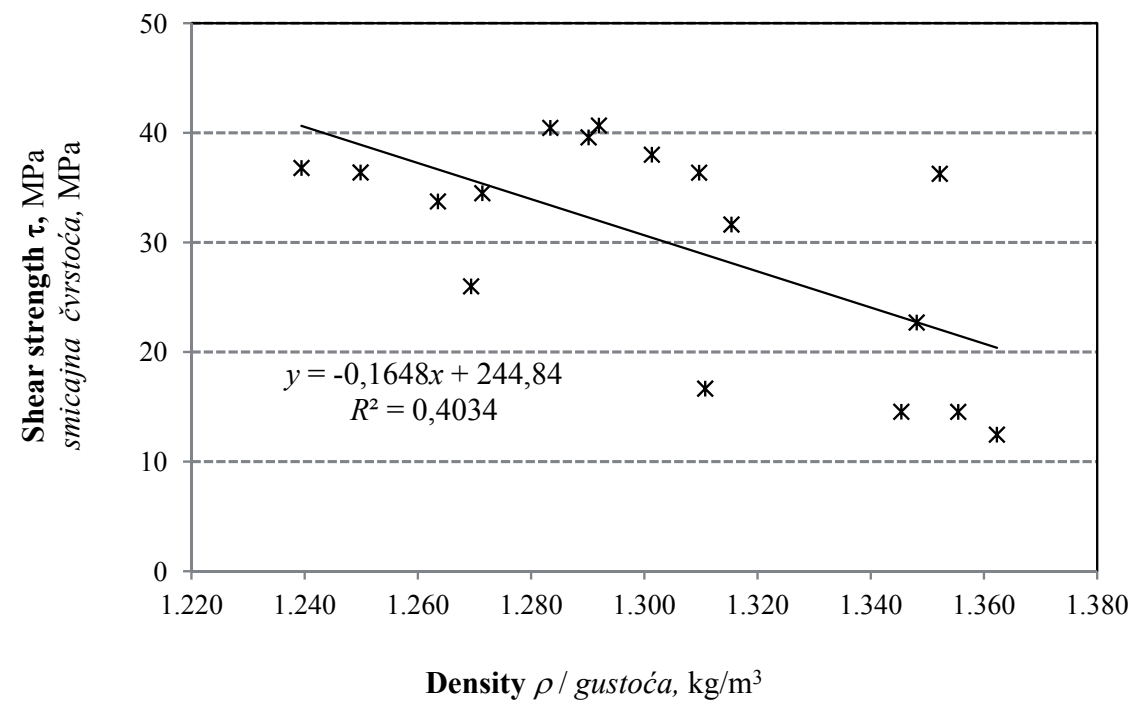

Figure 3 Influence of density on shear strength of xylite Slika 3. Utjecaj gustoće na čvrstoću smicanja ksilita 


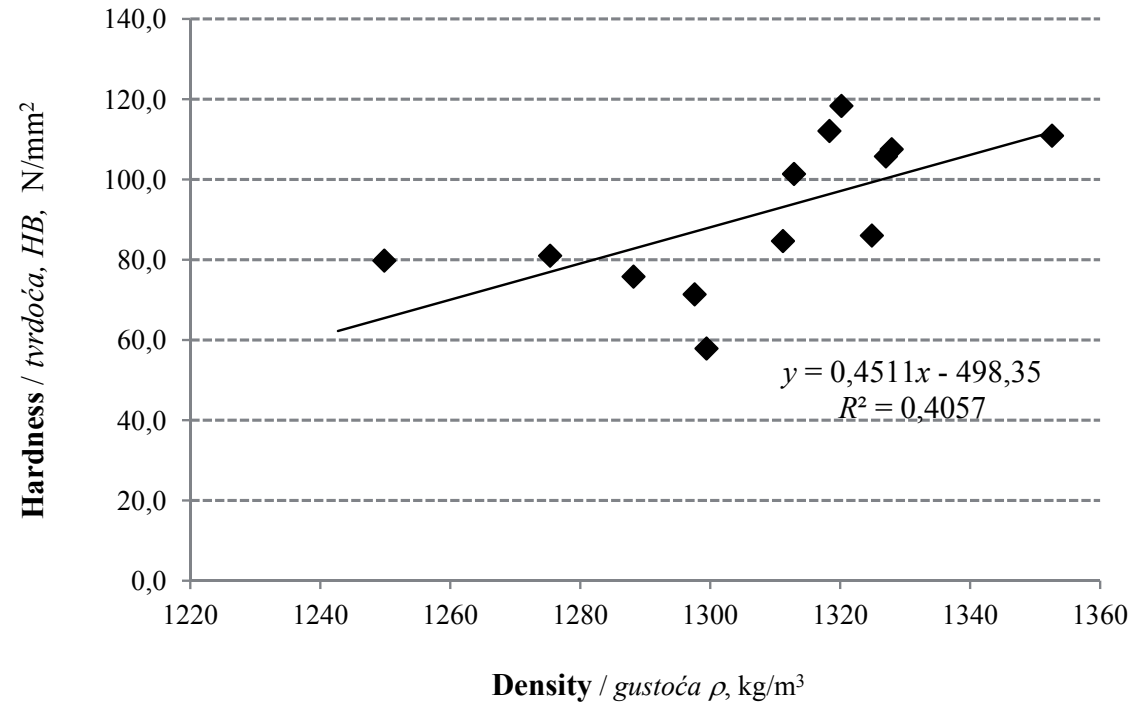

Figure 4 Influence of density on hardness of xylite.

Slika 4. Utjecaj gustoće na tvrdoću ksilita

density of xylite would presumably increase its mechanical properties. The results do not confirm this, since higher density of xylite is also caused by the presence of mostly bound water and frequently collapsed structure. $M O E$ and $M O R$ of xylite is likely to be reduced by temperature just as $M O E$ and $M O R$ of many current wood species of similar density.

Due to densification, xylite is characterized by high hardness. Great variability in shear strength is mainly attributed to structural and chemical changes. Namely, during the process of carbonization, polyoses are subject to major changes with significant influence on bonding between cellulose and matrix. The consequences are visualized as typical brittle fracture of $\mathrm{xy}$ lite.

Additionally, the use of xylite is recommended in places not exposed to dynamic loading.

\section{Acknowledgement - Zahvala}

The material was obtained in the framework of the project: Proučevanje in raziskovanje ksilita Standardizacija mikrolitotipov lignita in njihova dimenzijska stabilizacija, co-founded by Premogovnik Velenje d.d., Slovenia.

\section{REFERENCES}

\section{LITERATURA}

1. Brezigar, A., 1985/86: Premogova plast Rudnika lignita Velenje $=$ Coal seam of the Velenje coal mine. Geologija, 28/29: 319-336.

2. Crook, F. M., Nelson, P. F., Sharp, D. W., 1965: An examination of ancient victorian woods. Holzforschung. 19. 153 - 156. http://dx.doi.org/10.1515/hfsg. 1965.19.5.153

3. Dinwoodie, J. M., 2000: Timber. Its nature and behaviour. BRE London \& New York. 257 p. http://dx.doi. org/10.4324/9780203477878.fmatt
4. Drobniak, A; Mastalerz, M., 2006: Chemical evolution of Miocene wood: Example from the Belchatow brown coal deposit, central Poland. International Journal of Coal Geology 66: 157- 178. http://dx.doi.org/10.1016/j. coal.2005.06.004

5. Drovenik, M., 1982: Nahajališča premogov. Ljubljana. Univerza Edvarda Kardelja v Ljubljani, Fakulteta za naravoslovje in tehnologijo: $120 \mathrm{pp}$.

6. EN 1534:2011. Wood flooring - Determination of resistance to indentation (Brinell) - Test method, $10 \mathrm{p}$.

7. EN 310:1996. Wood-based panels - Determination of modulus of elasticity in bending and of bending strength, $12 \mathrm{p}$.

8. Fengel, D., 1991: Aging and fossilization of wood and its components. Wood Science and Technology, 25, 3, 153177. http://dx.doi.org/10.1007/BF00223468

9. Gorišek, Ž.; Čufar, K.; Straže, A., 2012: Charaterization of anatomical structure and basic physical properties of Velenje xylite. Zbornik gozdarstva in lesarstva. 98: 2738.

10. Gorišek, Ž.; Straže, A., 2014: Evaluation of material characteristics of xylite - Part 2 Characterisation of drying defects. Drvna industrija (in print).

11. Hatcher, P. G.; Breger, I. A.; Earl, W. L., 1981: Nuclear magnetic resonance studies of ancient buried wood - I. Observations on the origin of coal to the brown coal stage. Organic Geochemistry, 3 (1-2): 49-55. http:// dx.doi.org/10.1016/0146-6380(81)90013-9

12. Hatcher, P. G.; Breger, I. A.; Szeverenyi, N.; Maciel, G. E., 1982: Nuclear magnetic resonance studies of ancient buried wood - II. Observations on the origin of coal from lignite to bituminous coal. Organic Geochemistry, 4(1): 9-18. http://dx.doi.org/10.1016/0146-6380(82)90003-1

13. Justin, B.; Markič, M., 2005: Mikroskopska analiza velenjskega ksilita. Velenje, ERICo Velenje, Inštitut za ekološke raziskave: $22 \mathrm{p}$.

14. Lechien, V.; Rodriguez, C.; Ongena, M.; Hiligsmann' S.; Rulmont, A.; Thonart, P., 2006: Physicochemical and biochemical characterization of non-biodegradable cellulose in Miocene gymnosperm wood from the Entre-Sambre-et-Meuse, Southern Belgium. Organic Geochemistry, 
- Gorišek, Straže: Evaluation of Material Characteristics of Xylite - Part 1...

37 (11): 1465-1476. http://dx.doi.org/10.1016/j.orggeochem.2006.07.002

15. Markič, M.; Sachenhofer, R. F., 2010: The Velenje lignite - Its petrology and genesis. Geološki zavod Slovenije, Ljubljana, 233 p.

\section{Corresponding address:}

Associate Professor ŽELJKO GORIŠEK, Ph.D.

University of Ljubljana, Biotechnical Faculty

Department of Wood Science and Technology

Rožna dolina, Cesta VIII/34

1000 Ljubljana, SLOVENIA

e-mail: zeljko.gorisek@bf.uni-lj.si 